\title{
Comparison of Xanthomonas arboricola pv.juglandis isolates from walnut trees grown in Romania and Hungary
}

\author{
Bandi, A. ${ }^{1,2}$, Tóth, M. ${ }^{1}$ \& Hevesi, M. ${ }^{1}$ \\ ${ }^{I}$ Department of Pomology, Faculty of Horticultural Science, Corvinus University of Budapest, \\ 1118 Budapest, Villányi str. 29-43, Hungary \\ ${ }^{2}$ Department of Horticulture, Faculty of Technical Science, Sapientia Hungarian University of Transylvania, \\ Tg-Mures/Corunca, Sighisoara str. 1C. Romania
}

\begin{abstract}
Summary: Among diseases that affect walnut, bacterial blight is considered the most important one in all walnut growing areas both from Hungary and Romania. For the determination of susceptibility/resistance of walnut cultivars in our posterior work planned, 61 bacterial isolates were collected from walnuts showing symptoms of blight, with the purpose of isolating Xanthomonas arboricola pv. juglandis (Xaj). The characteristic $X a j$ colonies, frequently present as saprophytes in the infected plant tissues, were separated from other bacteria according to their morphology, yellow colour, hydrolysis of starch, and oxidation of glucose. All isolates were tested for pathogenicity by hypersensitive reaction on tobacco leaves (Nicotiana tabacum L.), bean pods (Phaseolus vulgaris L) and unripe nuts (Juglans regia L.). Determination of taxonomy of the selected isolates denotes a possible subdivision (races, biotypes) of Xaj occurring in different geographical areas, API 20NE and API 50CH kits were used. Hungarian and Romanian strains showed a high degree of similarity of carbohydrate utilization but slightly differed from the type strain. All were $\mathrm{Cu}$-sensitive.
\end{abstract}

Keywords: biochemical comparison, copper resistance, walnut, Xanthomonas arboricola pv. juglandis

\section{Introduction}

The Persian (English) walnut (Juglans regia L.) is very sensitive to a number of abiotic and biotic factors. Two of the most important abiotic factors are the autumn frost, sometimes leading to tree death, and the late spring frost, having an effect on stem form. The main biotic damage factor is Xanthomonas arboricola pv. juglandis (Pierce 1901) Vauterin et al., 1995 (Xaj), damages leaves and young shoots in humid and mild climate and after several rainy summers some trees might even die (Fernandez-Lopez and Pereira, 1997).

The bacterial blight disease is one of the most important diseases of Persian walnut (Loreti, 2001) and is widespread in walnut growing areas. The disease severity depends on the weather, which may be different in each year. It causes severe damage to leaves, twigs, buds, petioles, rachides, male and female catkins, nutlets and kernels, and it is considered a major cause of reduction in fruit yield and tree vigour (Belisario et al., 1999) (Figure 1.).

The inoculum is spread by the action of wind and rain, and infection requires the presence of moisture (Miller and Bollen, 1946, Olson et al., 1997). The damage produced by this pathogen is favoured by wet springs, with high humidity. Rainy springs, dew, and continual high humidity conditions are favourable for the development of severe blight, resulting in significant crop loss (Belisario, 1997). Especially if this happens just before and after the flowering time, it may cause losses up to $80 \%$ of the crop (Charlot and Radix, 1993; Miller, 1934).

The control of the disease is difficult, since large walnut trees are not easy to treat and because more and more copperresistant Xaj strains are developing (Solar et al., 2007; Giovanardi et al., 2010). To date, no Xaj resistance has been found in walnut. Differences have been detected only in the severity of symptoms shown by cultivars planted in the same environment (Frutos and López, 2012).

One of the main objectives of breeding and production improvement activities is to produce resistant cultivars. The production and introduction into production of resistant cultivars is one of the possibilities for preventive measures against the walnuts xanthomonas infection.

In several walnut producing areas of the world plant breeding is practiced, although the resistance of resistant cultivars improved in distant places is questionable against bacterias from walnut population of other production lands.

Many bacterial species show considerable variability in biochemical characters.

Hayward has distinguished isolates of Pseudomonas (Ralstonia) solanacearum on the basis of utilization of three hexose alcohols and three sugars and proposed subdivision of the species to biovars (biotypes) (Hayward, 1964).

Scortichini has concluded that genetic diversity exists among Xaj strains from different geographical areas of the 
world,for instance from Europa and California (Scortichini et al., 2001). Consequently a breeding programme for a long-lasting resistance should take into account different or similar potential virulence of the pathogen according to their geographical areas.

We considered the comparative analyses of the Xaj strains isolated in Hungary and Romania by means of biochemical methods necessary because supposedly walnut varieties may differ in the susceptibility to the bacterial pathogen in Hungary and Romania, and the potential of virulence of $\mathrm{Xaj}$ could also be different according to the biotype and race.
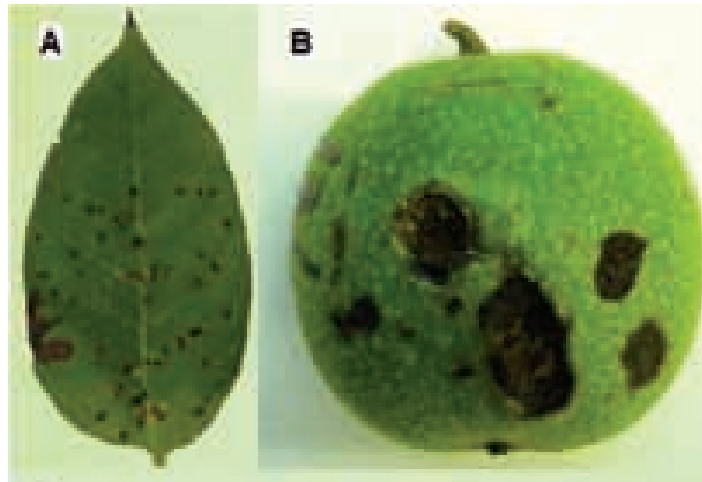

D

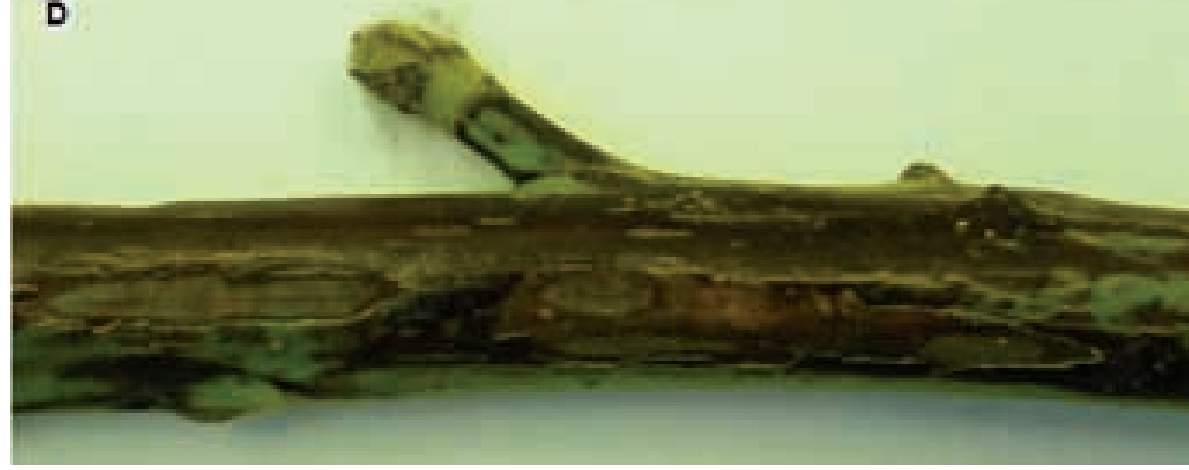

Figure 1. Bacterial blight symptoms on walnut leaves, immature fruits, kernels and young shoots conducted in the bacteriology laboratory of the Department of Pomology of Corvinus University of Budapest. $61 \mathrm{Xaj}$ isolates were examined. These were chosen based on the colony growth characteristics (yellow pigment production, smooth, mucoid, convex colony type, oxidative breakdown of glucose, hypersensitive reaction on tobacco leaves)

Once they were identified, they were placed in the DNA database of the NATIONAL COLLECTION OF AGRICULTURAL AND INDUSTRIAL Microorganisms, Corvinus University of Budapest Hungary.

The ability to induce hypersensitive reaction was examined on tobacco leave (Nicotiana tabacum L.) (Klement, 1963) and bean pod (Phaseolus vulgaris L), the pathogenicity test was controlled on unripe walnut fruits, similarly we used an isolate from the husk of the walnut fruit from Hungary B02489 (HU) and one from Transylvania B02490 (RO) showing a similar degree of infection (virulence).

As a reference to the biochemical analyses of the two isolates (henceforth strains) we used the NCPPB 411 strain, brought from the National Collection of Plant Pathogenic Bacteria, United Kingdom (NCPPB), deposited also in the NCAIM, Budapest, Hungary (http://ncaim.uni-corvinus.hu).

During the biochemical evaluations, the exploitation of the substrates were made on API rapid diagnostic kits (API 20NE és API 50CH bioMérieux, France), following the instructions of the manufacturer. The evaluations were made after 24 and 48 hours (Figure 2).

\section{Materials and methods}

Parts of the plants showing symptoms of xanthomonas infection have been collected from different walnut producing areas of Hungary and Transylvania.

In order to carry out the identification of the pathogenic agent, the examination of its morphological, biochemical and physiological characteristics, pathogenicity tests were
The API 50CH kit is based on observing the colour change: according to their ability to utilize or oxidize disaccharides and hexose alcohols, if that particular bacteria utilizes the carbohydrate, the original red coloured solution is changing to yellow (acid production), while in the case of positive test result, during gelatin breakdown the gelatin is liquefied (hydrolysis of gelatin) and a black colour reaction appears. For inoculation we prepared a bacteria suspension with a concentration of $6 \times 10^{8}$ cells $/ \mathrm{ml}$ of 24 h-old cultures grown on Nutrient agar substrate. The incubation temperature was $28^{\circ} \mathrm{C}$.

Evaluations, based on the colour changes were realised daily for six days, following the degree of carbohydrate utilization (Figure 3). The resistancy tests of the isolates were conducted and the starch hydrolysis capacity was checked.

Figure 2. The 48 hours result of API 20NE diagnostic kit for B02489 (HU) isolate 


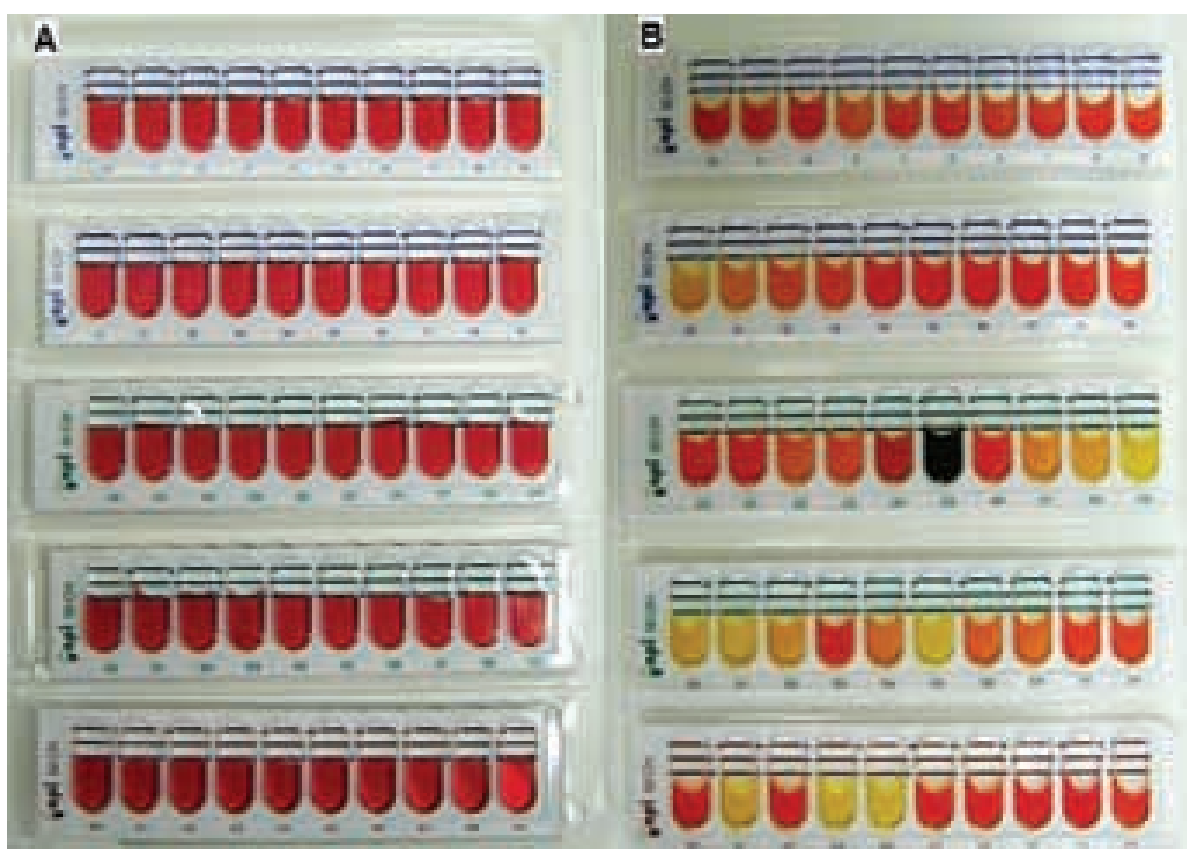

Figure 3. Carbohydrates utilized by B02489 (HU) isolates in different times (A: 0 h; B: 144 h) (0: control; 1-49 different carbohydrates; colour changes indicate the decomposition)

(N-Acetyl Glucosamine, D-Saccharose, D-melezitose, D-raffinose, Glycogen) less, than the B02490 (HU) and B02489 (RO) strains.

The difference of the carbohydrate utilization between the USA and EU strains could be important in the resistance breeding, if in the case of cultivars is combined with different virulence (specific host change). According to this difference we have to choose cultivars resistant to the races present on the particular growing area, or during the breeding it is advisable to take those phenotypes from the population, which are resistant against the local varieties, using them as parents in crossbreeding.

Considering the identical carbohydrate-utilization of the isolates from Hungary and Transylvania, we can draw the conclusion that during

\section{Results}

Neither of the collected $61 \mathrm{Xaj}$ strain proved to be Copperresistant. All of the strains hydrolysed starch. The results of API 20NE system showed that B01395 (USA) strain, and B02490 (HU), B02489 (RO) Xaj strains, analysed in details assimilated substrates in identical ways. Some difference could be noticed only in the case of trisodium citrate.

The B02490 (HU) strain gave a negative reaction, while the B01395 (USA) and the B02489 (RO) strain gave a positive reaction.

Hevesi et al. (2004) determined the utilization of 49 types of carbohydrate in the case of Erwinia amylovora and grouped them according to the speed of carbohydrate breakdown.

We used this classification in our present study with API 50CH test (Biomérieux, Marcy l'Etoile, France).

Shami et al. (2013) found a difference in the utilization of cellobiose, maltose, mannose, fructose, citrate, dulcitol, adonitole, oxalate, surbose and sorbitol in the case of $14 \mathrm{Xaj}$ isolates isolated in the provinces Lorestan, Kordestan and Alborz from Iran.

According to our results, until the end of the 24-48 $\mathrm{h}$ time of reaction all the three analysed $X a j$ strains utilized three carbohydrates (Esculin ferric citrate, D-Lactose, Starch) from the 49 quickly and completely, while other four carbohydrates (D-Fucose, az L-Fucose, a D-Saccharose, D-Lactose) were utilized differently (Table 2).

Until the end of 72-96h, and $144 \mathrm{~h}$ time of reaction three (D-Glucose, D-Melibiose, D-Lyxose) and four (Amygdalin, D-Cellobiose) types of carbohydrates were utilized in equal proportion. The B02490 and B02489 strains utilized totally identical carbohydrates, with the difference that B02489 utilized them more quickly, while B02490 - more slowly. The control strain from the USA utilized five carbohydrates the resistance/susceptibility test it is sufficient to make the evaluation of cultivar with a mix of isolates. As a result we consider it is possible to accomplish the breeding of a cultivar which is intended to be xanthomonas-resistant.

Table 1. Results from API 20NE system

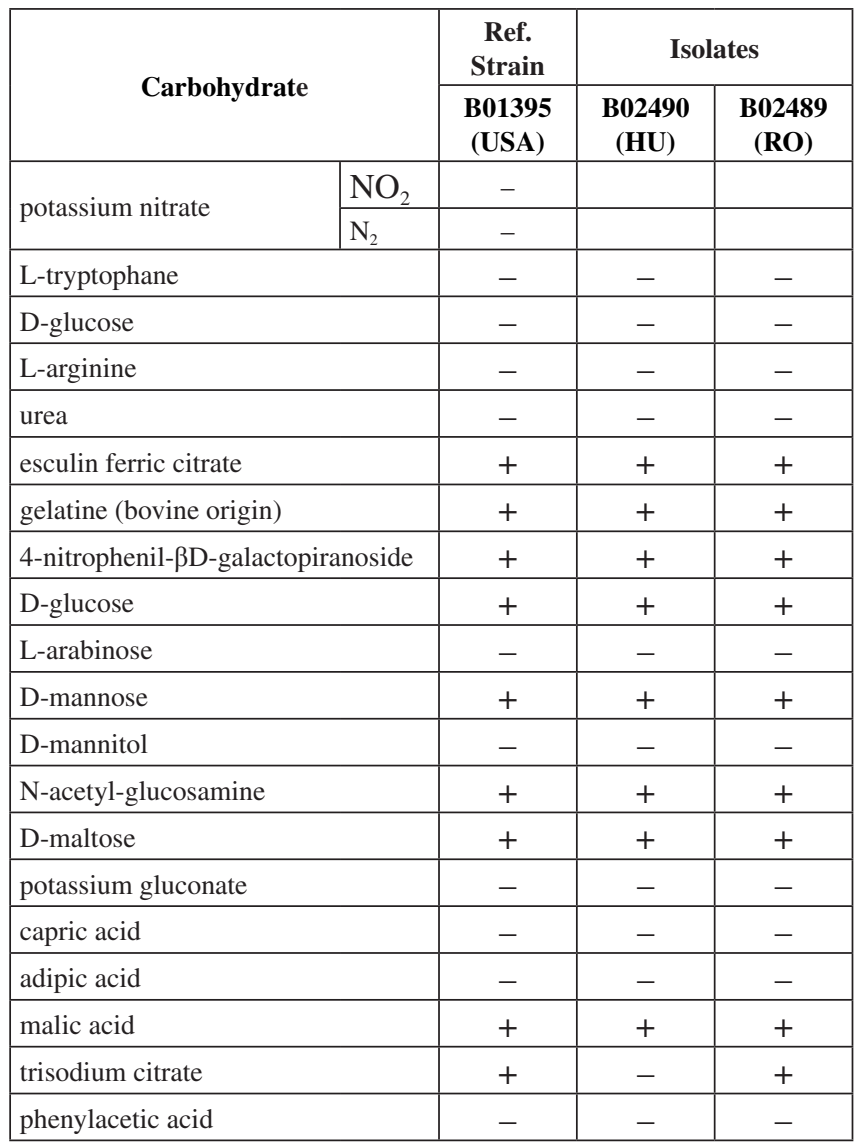


Table 2. Carbohydrates utilized by $X a j$ isolates using API $50 \mathrm{CH}$ system

\begin{tabular}{|c|c|c|c|c|c|}
\hline \multirow{2}{*}{\multicolumn{2}{|c|}{\begin{tabular}{|r|} 
Ref. Strain \\
B01395 (USA) \\
\end{tabular}}} & \multicolumn{4}{|c|}{ Isolates } \\
\hline & & \multicolumn{2}{|c|}{ B02490 (HU) } & \multicolumn{2}{|c|}{ B02489 (RO) } \\
\hline \multicolumn{6}{|c|}{ Utilized quickly, completly (24-48 h) } \\
\hline$N r$ & Carbohydrates & $N r$. & Carbohydrates & $N r$. & Carbohydrates \\
\hline 25 & $\begin{array}{l}\text { Esculin ferric } \\
\text { citrate }\end{array}$ & 25 & $\begin{array}{l}\text { Esculin ferric } \\
\text { citrate }\end{array}$ & 25 & $\begin{array}{l}\text { Esculin ferric } \\
\text { citrate }\end{array}$ \\
\hline 29 & D-Lactose & 29 & D-Lactose & 29 & D-Lactose \\
\hline 36 & Amidon (Starch) & 36 & Amidon (Starch) & 31 & D-Saccharose \\
\hline 44 & L-Fucose & & & 36 & Amidon (Starch) \\
\hline \multicolumn{6}{|c|}{ Utilized slowly, completly (72-96 h) } \\
\hline Nr. & Carbohydrates & Nr. & Carbohydrates & Nr. & Carbohydrates \\
\hline 3 & D-Arabinose & 11 & D-Glucose & 3 & D-Arabinose \\
\hline 10 & D-Galactose & 30 & D-Melibiose & 10 & D-Galactose \\
\hline 11 & D-Glucose & 31 & D-Saccharose & 11 & D-Glucose \\
\hline 12 & D-Fructose & 32 & D-Trehalose & 12 & D-Fructose \\
\hline 13 & D-Mannose & 35 & D-Raffinose & 13 & D-Mannose \\
\hline 28 & D-Maltose & 41 & D-Lyxose & 28 & D-Maltose \\
\hline 30 & D-Melibiose & 43 & D-Fucose & 30 & D-Melibiose \\
\hline 41 & D-Lyxose & 44 & L-Fucose & 32 & D-Trehalose \\
\hline 43 & D-Fucose & & & 35 & D-Raffinose \\
\hline \multicolumn{6}{|c|}{ Utilized slowly, weakly (144 h) } \\
\hline Nr. & Carbohydrates & $N r$. & Carbohydrates & $N r$ & Carbohydrates \\
\hline 23 & Amygdalin & 3 & D-Arabinose & 22 & $\begin{array}{l}\begin{array}{l}\text { N-AcetylGlu- } \\
\text { cosamine }\end{array} \\
\end{array}$ \\
\hline 27 & D-Cellobiose & 10 & D-Galactose & 23 & Amygdalin \\
\hline 32 & D-Trehalose & 12 & D-Fructose & 27 & D-Cellobiose \\
\hline & & 13 & D-Mannose & 34 & D-Melezitoze \\
\hline & & 22 & $\begin{array}{l}\text { N-AcetylGlu- } \\
\text { cosamine }\end{array}$ & 37 & Glycogen \\
\hline & & 23 & Amygdalin & & \\
\hline & & 27 & D-Cellobiose & & \\
\hline & & 28 & D-Maltose & & \\
\hline & & 34 & D-Melezitoze & & \\
\hline & & 37 & Glycogen & & \\
\hline \multicolumn{6}{|c|}{ Not utilized } \\
\hline$N r$ & Carbohydrates & $N r$. & Carbohydrates & $N r$ & Carbohydrates \\
\hline 1 & Glycerol & 1 & Glycerol & 1 & Glycerol \\
\hline 2 & Erythritol & 2 & Erythritol & 2 & Erythritol \\
\hline 4 & L-arabinose & 4 & L-arabinose & 4 & L-arabinose \\
\hline 5 & D-Ribose & 5 & D-Ribose & 5 & D-Ribose \\
\hline 6 & D-xylose & 6 & D-xylose & 6 & D-xylose \\
\hline 7 & L-xylose & 7 & L-xylose & 7 & L-xylose \\
\hline 8 & D-adonitol & 8 & D-adonitol & 8 & D-adonitol \\
\hline 9 & $\begin{array}{l}\text { Methyl- D- } \\
\text { xylopyranoside }\end{array}$ & 9 & $\begin{array}{l}\text { Methyl- D- } \\
\text { xylopyranoside }\end{array}$ & 9 & $\begin{array}{l}\text { Methyl- } \beta \text { D- } \\
\text { xylopyranoside }\end{array}$ \\
\hline 14 & L-sorbose & 14 & L-sorbose & 14 & L-sorbose \\
\hline 15 & L-rhamnose & 15 & L-rhamnose & 15 & L-rhamnose \\
\hline 16 & Dulcitol & 16 & Dulcitol & 16 & Dulcitol \\
\hline 17 & Inositol & 17 & Inositol & 17 & Inositol \\
\hline 18 & D-manitol & 18 & D-manitol & 18 & D-manitol \\
\hline 19 & D-sorbitol & 19 & D-sorbitol & 19 & D-sorbitol \\
\hline 20 & \begin{tabular}{|l|} 
Methyl- d- \\
mannopyranoside
\end{tabular} & 20 & $\begin{array}{l}\text { Methyl- } \alpha \text { d- } \\
\text { mannopyranoside }\end{array}$ & 20 & $\begin{array}{l}\text { Methyl- } \alpha \text { d- } \\
\text { mannopyrano- } \\
\text { side }\end{array}$ \\
\hline
\end{tabular}

\begin{tabular}{|c|c|c|c|c|c|}
\hline \multirow{2}{*}{\multicolumn{2}{|c|}{$\begin{array}{r}\text { Ref. Strain } \\
\text { B01395 (USA) } \\
\end{array}$}} & \multicolumn{4}{|c|}{ Isolates } \\
\hline & & \multicolumn{2}{|c|}{ B02490 (HU) } & \multicolumn{2}{|c|}{ B02489 (RO) } \\
\hline 21 & $\begin{array}{l}\text { Methyl- D- } \\
\text { glucopyranoside }\end{array}$ & 21 & $\begin{array}{l}\text { Methyl- } \alpha \mathrm{D}- \\
\text { glucopyranoside }\end{array}$ & 21 & $\begin{array}{l}\text { Methyl- } \alpha \mathrm{D}- \\
\text { glucopyranoside }\end{array}$ \\
\hline 22 & \begin{tabular}{|l}
$\begin{array}{l}\text { N-AcetylGlu- } \\
\text { cosamine }\end{array}$ \\
\end{tabular} & 24 & Arbutin & 24 & Arbutin \\
\hline 24 & Arbutin & 26 & Salicin & 26 & Salicin \\
\hline 26 & Salicin & 33 & Inulin & 33 & Inulin \\
\hline 31 & D-Saccharose & 38 & Xylitol & 38 & Xylitol \\
\hline 33 & Inulin & 39 & Gentiobiose & 39 & Gentiobiose \\
\hline 34 & D-melezitose & 40 & D-turanose & 40 & D-turanose \\
\hline 35 & D-raffinose & 42 & D-tagatose & 42 & D-tagatose \\
\hline 37 & Glycogen & 45 & D-arabitol & 45 & D-arabitol \\
\hline 38 & Xylitol & 46 & L-arabitol & 46 & L-arabitol \\
\hline 39 & Gentiobiose & 47 & $\begin{array}{l}\text { Potassium } \\
\text { gluconate }\end{array}$ & 47 & \begin{tabular}{|l}
$\begin{array}{l}\text { Potassium } \\
\text { gluconate }\end{array}$ \\
\end{tabular} \\
\hline 40 & D-turanose & 48 & \begin{tabular}{|l} 
Potassium \\
2-ketogluconate
\end{tabular} & 48 & \begin{tabular}{|l} 
Potassium \\
2-ketogluconate
\end{tabular} \\
\hline 42 & D-tagatose & 49 & $\begin{array}{l}\text { Potassium } \\
\text { 5-ketogluconate }\end{array}$ & 49 & $\begin{array}{l}\text { Potassium } \\
\text { 5-ketogluconate }\end{array}$ \\
\hline 45 & D-arabitol & & & & \\
\hline 46 & L-arabitol & & & & \\
\hline 47 & $\begin{array}{l}\text { Potassium } \\
\text { gluconate }\end{array}$ & & & & \\
\hline 48 & $\begin{array}{l}\text { Potassium } \\
\text { 2-ketogluconate }\end{array}$ & & & & \\
\hline 49 & $\begin{array}{l}\text { Potassium } \\
\text { 5-ketogluconate }\end{array}$ & & & & \\
\hline
\end{tabular}

\section{Discussion}

The present study provides comprehensive information regarding the carbohydrate utilization of Xaj bacteria. Based on our results we determined the groups of carbohydrates utilized in a various degrees by the pathogen: carbohydrates utilized quickly and completely, carbohydrates utilized slowly and completely, carbohydrates utilized weakly and to a lesser extent, and non-utilized carbohydrates.

We suppose that carbohydrates utilized quickly and completely, and the ones utilized slowly and completely influence the extent and spread of the infection.

There wasn't a difference between the types of carbohydrates in the case of B02490 (HU) and B02489 (RO) isolates, only in the speed of breakdown.

The B01395 (USA) strain utilized less carbohydrate (see 22, $31,35,37$ carbohydrates), than the EU isolate.

Our results support that widespread opinion, according to which the walnut (Juglans regia L.) has a weak ability to adapt. Therefore in the case of the production in a remote area from the breeding place, not only the manifestation of the biological potential of the cultivar is low, but, as the consequence of the different biotic and abiotic stress factors, it can also suffer damages. Our walnut production has to be based on locally bred cultivars, which are adapted to this specific environment. 
Due to the identical carbohydrate utilization of the two strains from Transylvania B02489 (RO) and Hungary B02490 (HU), it is assumed that these belong to the same biotype, and they have been subjected to the same stress factors. At the same time the strain originated from the USA (B01395), because of its different carbohydrate utilizing makes us reach the conclusion that we have to be precautious with the naturalization of cultivars from remote places, and resistance against local varieties has to be analysed.

\section{Acknowledgements}

This research was supported by the TÁMOP 4.2.1./B-09/01/ KMR/2010-0005 project.

\section{References}

Belisario, A., Palangio, C., Zoina, A. (1997): Suscettibilita e fattori predisponenti a Xanthomonas campestris pv. juglandis in vivaio di noce comune. Informatore Fitopatologico, 4: 60-64.

Belisario, A. (1997): Susceptibility and factors predisposing to Xanthomonas campestris pv. juglandis in walnut nurseries. Informatore Fitopatologica, 47: 60-63.

Belisario, A., Zoina, A., Pezza, L., Luongo, L. (1999): Susceptibility of species of Juglans to pathovars of Xanthomonas campestris. Eur J. Forest Pathol, 29: 75-80.

Charlot, G., Radix, P. (1993): Walnut bacterial blight. Phenolic compounds and resistance. Infos CTIFL, 94: 31-32.

Fernandez-Lopez, J., Pereira, S. (1997): Genetic control of growth in Juglans regia seedlings from open families of different provenances. Acta Hort. 41: 69-75.

Frutos, D., López, G. (2012): Search for Juglans regia genotypes resistant/tolerant to Xanthomonas arboricola pv. juglandis in the framework of COST Action 873. Journal of Plant Pathology 94 (1sup): S1.37-S1.46.
Giovanardi, D., Dallai, D., Manceau, C., Stefani, E. (2010): An insight in some population features of Xanthomonas arboricola pv. juglandis. COST Action 873 "Bacterial Diseases of Stone Fruits and Nuts" Jürmala, Latvia. September 13-15; 2010.

http://www.cost873.ch/_uploads/_files/Giovanardi_STSMReport_ XajPopulationStudy.pdf

Hayward, A. C. (1964): Characteristics of Pseudomonas solanacearum. J. of Applied Bacteriology, 27: 265_277.

Hevesi, M., Farkas, Á., Kása, K., Orosz-Kovács, Zs. (2004): Carbohydrate utilization of Erwinia amylovora in vitro. International Journal of Horticultural Science. 10 (2): 31-34.

Klement, Z. (1963): Rapid detection of the pathogenicity of phytopathogenic pseudomonads. Nature. 199-300.

Miller, P. W. (1934): Walnut blight and its control in the Pacific Northwest USA. Department of Agriculture. 331: 13 pp.

Miller, P.W., Bollen, W.B. (1946): Walnut bacteriosis and its control. U.S. Dept. Agr., Bur. Plant Industry, Soils and Agr. Eng., Oregon State College, Corvallis. Agr. Expt. Sta. Tech. Bul. 9.

Olson, W. H., Buchner, R. P., Adaskaveg, J. E., Lindow, S. E. (1997): Walnut blight control in California. Acta Hort. 442: 173-188.

Scortichini, M.,Marchesi, U., Prospero, P. Di. (2001): Getetic diversity of Xanthomonas arboricola pv. juglandis (synonyms: $X$. campestris pv. juglandis; X. juglandis pv. juglandis) strains from different geographical areas shown by repetitive polymerase chain reaction genomic fingerprinting. Phytopathology. 149: 325-332.

Shami, M., Ghasemi, A., Alizade Ali-Abadi, A., Eskandari, A. (2013): Genetic Diversity and Phylogenetic Study of Xanthomonas arboricola pv. juglandis the Causal Agent of Walnut Bacterial Blight Disease. Journal of Nuts. 4 (4): 57-62.

Solar, A., Jakopic, J., Veberic, R., Stampar, F. (2007): Phenolic compounds as a potential marker of walnut resistance against Xanthomonas arboricola pv. juglandis. Cost 873,WG3/WG4 Joint Meeting, Murcia, Spain.

http://www.cost873.ch/_uploads/_files/m_Solar_murcia.pdf

Vauterin, L, Hoste, B, Kersters, K, Swings, J. (1995): The relationships within the genus Xanthomonas and a proposal for a new classification. International Journal Systematic Bacteriology. 45: 472-489. 